\title{
О мозаичных инфракрасных фотоприемниках сверхвысокой размерности на основе многослойных структур с квантовыми ямами
}

\author{
А.И. Козлов ${ }^{1)}$, А.Р. Новоселов ${ }^{2)}$, М.А. Демьяненко ${ }^{1)}$, В.Н. Овсюк ${ }^{1)}$ \\ ${ }^{1}$ Институт физики полупроводников им. А.В.Ржанова СО РАН, \\ Новосибирск, 630090, пр-т Акад. Лаврентьева, 13 \\ ${ }^{2}$ Новосибирский филиал ИФП СО РАН “Конструкторско-технологический институт прикладной \\ микроэлектроники” (КТИ ПМ), Новосибирск, 630090, пр-т Акад. Лаврентьева, 2/1 \\ тел: +7 (383) 333-1957, факс: +7 (383) 333-2771, эл. почта: kozlov@isp.nsc.ru
}

DOI 10.34077/RCSP2019-140

Одним из перспективных путей достижения сверхвысокой размерности инфракрасных фотоприемников (ИК ФП) является мозаичный принцип построения. Мозаичные фотоприемники (МФП) сверхвысокой размерности создают посредством установки стык в стык друг к другу фотоприемных субмодулей меньшего, приемлемого для изготовления формата [1-6]. Мозаичный принцип создания ИК ФП сверхвысокой размерности на основе многослойных структур с квантовыми ямами (МСКЯ): "слепая зона", области повреждения полупроводникового материала и многослойных микроструктур, зазор между кристаллами субмодулей показаны на рис. [4].

МФП сверхвысокой размерности обеспечивают предельную эффективность параллельного сбора видеоинформации при стандартной частоте считывания фотосигналов субмодулей, и практически неограниченное повышение чувствительности путем структурирования фоточувствительных

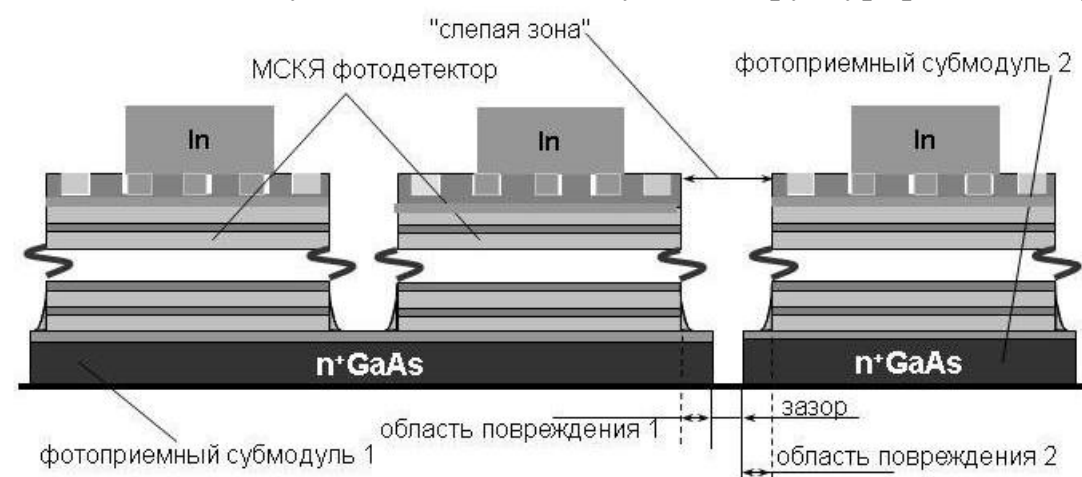

элементов (ФЧЭ) с большой суммарной площадью объединенной области фоточувствительности [1]. Формат МФП набирается на основе мозаичного принципа, а размеры структурированных ФЧЭ формируются исходя из требований чувствительности $[1,2]$. МФП может обеспечивать формирование комбинированной, т.е. совмещающей широкополосную и узкополосную части, спектральной характеристики фоточувствительности за счет использования разных кристаллов субмодулей на основе ФЧЭ, работающих в разных спектральных диапазонах, например, КРТфотодиодов и МСКЯ-фотодетекторов, или например, ИК и терагерцовых микроболометров [1-4]. Представлена конгруэнтность возможностей мозаичной технологии для разных определяющих материалов $[1,3,6]$.

В работе приведен достигнутый технологический уровень прецизионной микросборки кристаллов субмодулей в МФП, размер областей повреждения полупроводниковых материалов и микроструктур на краях кристаллов составляет для кремниевых мультиплексоров и матриц ФЧЭ на базе МСКЯ $\leq 5$ мкм, зазор между смежными кристаллами не более 2 мкм $[1,3,6]$. Выполнен анализ размерности "слепых зон". Рассмотрены способы уменьшения "слепых зон". Развиты конструктивнотехнологические принципы создания МФП сверхвысокой размерности с предельной эффективностью преобразования изображений [1].

\section{Литература}

[1] Козлов А.И., Новоселов А.Р. и др. Оптический журнал. 2018. Т.85, №2. С.60-66.

[2] Козлов А.И., Демьяненко М.А. и др. Автометрия. 2016. Т.52, №2. С.115-121.

[3] Новоселов А.Р. Автометрия. 2016. Т.52, №1. С.116-121.

[4] Козлов А.И., Демьяненко М.А. и др. Автометрия. 2015. Т.51, №2. С.110-118.

[5] Козлов А.И., Новоселов А.Р. и др. Оптический журнал. 2014. Т.81, №3. С.35-43.

[6] Пат. РФ № 2509391. Новоселов А.Р. Опубл. 10.03.2014. Бюл. №7. 